DOI: 10.12797/Politeja.12.2015.39.09

Katarzyna GÓRAK-SOSNOWSKA

Szkoła Główna Handlowa w Warszawie

kgorak@sgh.waw.pl

\title{
BRANDING CALIPHATE
}

\section{ISIS, AL-BAGHDADI I NOWA ERA \\ GLOBALNEGO DŻIHADYZMU}

ABSTRACT Branding caliphate. ISIS, Al-Baghdadi and the new era of global jihadism In Summer 2014 Abu Bakr al-Baghdadi, the leader of the Islamic State of Iraq and Al-Sham declared a caliphate in Iraq and Syria. By referring to the marketing technique of branding the author analyzes how the caliphate is created in the public space. In this case branding recalls the classical techniques used by Islamists (takfir, fighting bida'), but also means such things as using new information technologies and sophisticated forms of violence. The marking success of caliphate is the bigger that it is innovative, is an Utopia that became real and supports negative Western stereotypes about Islam.

Keywords: terrorism, caliphate, Islam, Iraq, jihadism

Słowa kluczowe: terroryzm, kalifat, islam, Irak, dżihadyzm 
$\mathrm{P}$ ojęcie branding związane jest z marketingiem i oznacza budowanie świadomości marki (ang. brand). Jednym z najbardziej istotnych celów jest wykreowanie bądź utrzymanie pozytywnego wizerunku marki, co powinno przełożyć się na wzrost jej wartości. W przypadku radykalnych muzułmańskich nurtów fundamentalistycznych, wykorzystujących przemoc do osiągania swoich celów ${ }^{1}$, trudno mówić o pozytywnym wizerunku, chyba że dokona się relatywizacji przyjętych kryteriów i grupy docelowej.

Na przełomie czerwca i lipca 2014 roku powołano do życia nowy twór - Państwo Muzułmańskie, znajdujące się na terenie Iraku i Syrii, o ustroju kalifatu. Na czele tego quasi-państwa stoi kalif Ibrahim Awwad, który wcześniej nosił pseudonim Abu Bakr al-Baghdadi i był liderem organizacji o nazwie Muzułmańskie Państwo Iraku i asz-Szamu (arab. ad-Daula al-Islamijja fi-l-Irak wa-sz-Szam - ISIS), obecnie znanej jako Państwo Muzułmańskie (arab. Ad-Daula al-Islamijja).

Państwo Muzułmańskie nie jest pierwszą próbą utworzenia kalifatu po jego zniesieniu w 1924 roku przez Mustafę Kemala Atatürka², zyskało jednak szczególną medialną atencję. Wydaje się, że wychodzi ona poza zagrożenie o charakterze politycznym czy militarnym związane z tym, że nowy kalifat założyła radykalna organizacja terrorystyczna, której nie należy lekceważyć chociażby dlatego, że kontroluje znaczną część Syrii i Iraku, a także nie przebiera w stosowanych środkach przemocy. Kluczową rolę zdaje się odgrywać islam i sposób wykorzystywania go przez ISIS w swojej działalności. Ta zaś charakteryzuje się dużą brutalnością i rozmachem, a zatem łatwo i szybko dociera do środków masowego przekazu.

Celem artykułu jest analiza sposobów kreowania przez ISIS ${ }^{3}$ marki swojego naj-

1 Unikam wchodzenia w meandry różnic definicyjnych między islamizmem, salafizmem i dżihadyzmem, gdyż pojęcia te zazębiają się w zakresie uzależnionym od tego, w jaki sposób są akurat stosowane przez poszczególnych autorów. $Z$ różnych opcji terminologicznych wybieram i będę konsekwentnie stosować „dżihadyzm” jako pojęcie nowe, acz stosunkowo dobrze zakorzenione w literaturze przedmiotu, na określenie radykalnego ruchu społecznego prowadzącego działalność zbrojną (czyli dżihad), ugruntowanego ideologicznie w skrajnej interpretacji islamu.

2 Po upadku kalifatu w ramach Imperium Osmańskiego założono m.in. kalifat szarifów na terenie Arabii Saudyjskiej, który istniał przez dwa lata, do 1925 roku. Ówczesny amir Mekki Husajn Ibn Ali ogłosił się kalifem, próbując nadać ciągłość instytucji kalifatu, a zarazem korzystając z tego, że nadarzyła się okazja do przejęcia tytułu. Jego kalifat nie zyskał jednak legitymacji w środowisku i został wkrótce wchłonięty przez wojska Ibn Su’udów. Tytuł kalifa, a właściwie chalifat al-masih (arab. następca Mesjasza) nosi także lider ahmadijji. Ahmadi postrzegają swój kalifat jako kontynuację dzieła kalifów sprawiedliwych. Kalifami nazywali się także imamowie zajdyccy z Jemenu (do lat 60.), lider Darul Islam Sekarmadji Maridjan Kartosuwiryo, który dążył do utworzenia kalifatu na terenie Indonezji, Abu Humam - obwołany kalifem przez dżihadystów z Peszawaru w 1993 roku, a także Meltin Kaplan - fundamentalistyczny imam z meczetu w Kolonii (Niemcy), wydalony z Niemiec w 2004 roku. Pokrewnego tytułu amir al-mumin (arab. przywódca wiernych) używa król Maroka (wywodzący się z Haszymitów), nosił go też sułtan Sokoto (mieszczącego się na terenie Nigerii sułtanatu, który na przełomie XIX i XX wieku był niezależnym kalifatem), a także Muhammad Umar - przywódca talibów.

3 W pracy konsekwentnie stosowany jest przymiotnik „muzułmański” zamiast anglicyzmu „islamski”. Organizacja al-Baghdadiego, niezależnie od fazy istnienia i nazwy, określana jest skrótem ISIS, który pochodzi od jej angielskiej nazwy (Islamic State of Iraq and Sham); MPISz, czyli skrót od nazwy polskiej, mógłby prowadzić do konfuzji. 
nowszego produktu, czyli kalifatu. Zarazem samo utworzenie kalifatu - a zatem urzeczywistnienie najbardziej dalekosiężnych planów klasyków radykalnego islamu (inna rzecz, czy mieli oni faktycznie na myśli realne państwo, czy też kalifat miał być nieosiągalnym celem, który określa jedynie kierunek działań) - wyznacza nową erę globalnego dżihadu. Oznacza bowiem, że dżihadyści mają własne terytorium, a nie działają z terenu Jemenu czy Afganistanu (nie mówiąc już o państwach niemuzułmańskich, takich jak Hiszpania czy Stany Zjednoczone).

Branding kalifatu przebiega na dwóch poziomach, o różnych celach i skierowanych do odmiennych grup docelowych. Pierwszą grupą docelową są inni muzułmanie. Choć al-Baghdadi zwrócił się do wszystkich muzułmanów, aby ci zaakceptowali jego zwierzchnictwo, z punktu widzenia strategii ISIS ważniejsza jest rekrutacja nowych członków, zarówno bojowników, jak i donatorów. Branding kalifatu może zatem polegać na ukazaniu go jako reprezentującego islam w „czystej formie” i walczącego z każdym przejawem religii, który nie mieści się w tych ramach. Podobną strategię stosowali wahhabici w Arabii Saudyjskiej czy talibowie w Afganistanie, jednak ISIS ma nad nimi zasadniczą przewagę: kalifat. Druga grupa docelowa jest znacznie bardziej zróżnicowana. Obejmuje bezpośrednich wrogów ISIS (wojsko irackie, konkurencyjne ugrupowania), a także potecjalnych wrogów (zwłaszcza Zachód). Tym razem branding może polegać na ukazaniu kalifatu jako państwa nie do pokonania, zatrważającego formami i zakresem stosowanej przemocy.

\section{OD AL-KA'IDY DO KALIFATU: DROGA MUZUŁMAŃSKIEGO PAŃSTWA IRAKU I ASZ-SZAMU (ISIS)}

Początki organizacji, która założyła Państwo Muzułmańskie, wiążą się z inwazją amerykańską na Irak i działalnością tamtejszej Al-Ka’idy pod przewodnictwem Jordańczyka Abu Musaba az-Zarkawiego (1966-2006). Iracki oddział Al-Ka’idy słynął nie tylko z dużej bitności, ale i okrucieństwa wobec ludności cywilnej. Działania te nie przyniosły organizacji popularności w kraju, a ponadto wywołały gniew ze strony władz Al-Ka'idy.

Po śmierci az-Zarkawiego w 2006 roku organizacja zmieniła nazwę na Muzułmańskie Państwo Iraku i skoncentrowała się na walce z żołnierzami amerykańskimi, a także lokalną ludnością szyicką. Sześć lat później nadarzyła się szansa na poszerzenie zakresu działalności. Obok, w Syrii, wybuchła wojna domowa, więc bojownicy Muzułmańskiego Państwa Iraku założyli na jej terenie nową komórkę - Dżabhat an-Nusra - która wkrótce stała się jedną z najlepiej zorganizowanych sił walczących w Syrii.

W maju 2013 roku Muzułmańskie Państwo Iraku poszerzyło swój geograficzny zasięg, zmieniając nazwę na Muzułmańskie Państwo Iraku i asz-Szamu (czyli tzw. Wielkiej Syrii) ${ }^{4}$ i ogłaszając wchłonięcie Dżabhat an-Nusry. Nie zgodziło się na to ani kie-

4 W Polsce przyjęła się w mediach druga nazwa - ISIL - oznaczająca Muzułmańskie Państwo Iraku i Lewantu. 
rownictwo tej organizacji, ani iracka Al-Ka’ida. Rozłam z Al-Ka’idą i Dżabhat an-Nusrą nie zmienił jednak kwestii zasadniczej: ISIS kontroluje obecnie znaczną część terytorium Iraku i Syrii, a jego oddziałów nie jest w stanie pokonać znacznie liczniejsza, lepiej uzbrojona (i teoretycznie lepiej wyszkolona) armia iracka.

ISIS wyznacza nową erę w globalnym dżihadyzmie nie tylko dlatego, że powołał kalifat; znacznie przewyższa swoim ekstremizmem i utopijnością klasyków dżihadu, których można określić jako old school ${ }^{5}$. Kończy się tym samym era zapoczątkowana przez Usamę ibn Ladina (wówczas mianem old school można by określić teoretyków Braci Muzułmanów z najradykalniejszym i najbardziej znanym Sajjidem Kutbem na czele) spektakularnym zamachem terrorystycznym na World Trade Center 11 września 2001 roku. Pod koniec czerwca 2014 roku ISIS ogłosił powstanie kalifatu na terenach Iraku i Syrii.

Analityk Hudson Institute Nibras Kazimi pisał już w 2008 roku o możliwości utworzenia kalifatu w Iraku przez tamtejszych dżihadystów. Jesienią 2006 roku ogłoszono powstanie na terenie Iraku emiratu o nazwie Muzułmańskie Państwo Iraku, którego emirem został Abu Umar al-Baghdadi. Anonimowy rzecznik ministerstwa informacji emiratu zawiadomil, że wzorem dla niego jest państwo założone przez Mahometa ${ }^{6}$. Informacja ta przeszła jednak bez echa w zachodnich mediach, może dlatego, że nic wówczas nie wskazywało na to, że samozwańczy emirat przekształci się kilka lat później w kalifat.

Ideologiczne i organizacyjne podwaliny pod nowe państwo stworzyć miał $\mathrm{Abu} \mathrm{Mu-}$ sab az-Zarkawi. Początkowo doprowadził do konsolidacji części organizacji dżihadystycznych pod szyldem irackiej Al-Ka’idy (funkcjonującej w Iraku pod nazwą Al-Ka’ida fi Bilad ar-Rafidajn) oraz utworzenia Madżlis Szura al-Mudżahidin - swego rodzaju rady konsultacyjnej skupiającej organizacje dżihadystyczne działające na terenie Iraku. Ustanowienie Muzułmańskiego Państwa Iraku było kolejnym krokiem na drodze instytucjonalizacji kalifatu, która nastąpiła jednakże już po śmierci az-Zarkawiego ${ }^{7}$. Abu Bakr al-Baghdadi ogłosił powstanie Państwa Muzułmańskiego (kalifatu) 29 czerwca 2014 roku. Jest to data symboliczna, bowiem na ten dzień przypadł początek ramadanu, miesiąca o szczególnym znaczeniu dla muzułmanów ze względu na post.

\section{JAKI KALIF, TAKI KALIFAT}

Abu Bakr al-Baghdadi nie jest prawdziwym imieniem przywódcy Państwa Muzułmańskiego, ale jednym z jego licznych pseudonimów. Ten jednak wyróżnia się silnym nawiązaniem do idei kalifatu, gdyż Abu Bakr był pierwszym kalifem - następcą proroka

5 C. Bunzel, The Caliphate's Scholar-in-Arm, Jihadica, 9 VII 2014, [online] http://www.jihadica.com/the-caliphate\%E2\%80\%99s-scholar-in-arms. Wszystkie strony internetowe były dostępne w maju 2014 roku.

6 Bajan ialan kijam "daulat al-irak al-islamijja”, Ministerstwo Informacji Muzułmańskiego Państwa Iraku, 15 XI 2008, [online] http://www.tawhed.ws/r?i=xsdcfre4.

7 N. Kazimi, The Caliphate Attempted. Zarqawi's Ideological Heirs, their Choice for a Caliph, and the Collapse of their Self-Styled "Islamic State of Iraq”, „Current Trends in Islamist Ideology” 2008, Vol. 7, s. 2-5. 
Mahometa. Zarazem był pierwszym z kalifów sprawiedliwych (arab. raszidun), którzy obejmowali kolejno władzę w tworzącym się imperium muzułmańskim. W ten sposób al-Baghdadi podkreśla swój związek z rodem Mahometa, a relacja ta dodatkowo wykracza poza sferę symboliczną, ponieważ swoją genealogię wywodzi on wprost z linii potomków proroka ${ }^{8}$.

Ze względu na to, że niewiele o nim wiadomo, al-Baghdadi zyskał przydomek „niewidzialnego szajcha" . W Internecie można znaleźć jego krótką biografię w języku arabskim, przetłumaczoną na język angielski, a spisaną przez jego anonimowego zwolenni$\mathrm{ka}^{10}$. Dostępne artykuły w gazetach bazują na tych samych kilku informacjach na temat życia al-Baghdadiego, wskazując na identyczne nieścisłości i niepewności faktograficz$n \mathrm{e}^{11}$. Innymi słowy, o al-Baghdadim nie wiadomo nic ponad to, że stoi na czele ISIS i że jest poszukiwanym przez Stany Zjednoczone terrorystą. Do czasu wygłoszenia piątkowej chutby (kazania) w mosulskim meczecie - już jako samozwańczy kalif - nikt go również nie widział. Zachowały się bowiem tylko dwa jego zdjęcia, a i do swoich towarzyszy miał przemawiać zza maski. Wszystko to niewątpliwie nadaje mu aurę tajemniczości, tworząc swoisty mit wokół jego osoby.

$\mathrm{Z}$ dostępnych powszechnie informacji wyłania się następujący obraz życia al-Baghdadiego: urodził się najpewniej na początku lat 70. w Samarze na terenie Iraku. Edukację ukończył ze stopniem naukowym doktora - niektóre wersje podają, że były to studia teologiczne na Uniwersytecie Nauk Muzułmańskich ${ }^{12}$ w Bagdadzie, inne zaś - że doktorat obronił z pedagogiki na Uniwersytecie Bagdadzkim. Jeszcze trudniej powiedzieć, dlaczego i kiedy wstąpił na drogę radykalnego islamu. Niektórzy wskazują na to, że był już zaangażowany w działalność dżihadystyczną za czasów Saddama $\mathrm{Hu}-$ sajna, inni wiążą ten krok z inwazją amerykańską na Irak w 2003 roku, gdy wstąpił w szeregi Al-Ka’idy, a jeszcze inni uważają, że radykalizacja wiąże się z zatrzymaniem al-Baghdadiego rok później przez siły amerykańskie i przetrzymywaniem go przez kilka miesięcy w więzieniu Camp Bucca na południu Iraku.

$8 \quad$ Nie jest to praktyka szczególna. Osoby, które mogą wywieść swoje pochodzenie z linii proroka Mahometa, cieszą się wśród muzułmanów szczególnym uznaniem i noszą tytuł honorowy sajjida. $\mathrm{Z}$ tego powodu praktyka ta bywa zarówno w historii, jak i współcześnie często nadużywana. Warto dodać, że swój rodowód wywodził od Mahometa także Saddam Husajn.

9 Profile: Abu Bakr al-Baghdadi, BBC News, 5 VII 2014, [online] http://www.bbc.com/news/world-middle-east-27801676.

10 P. van Ostaeyen, Abu Bakr al-Baghdadi - a Short Biography of the ISIS Sheikh, 15 VII 2013, [online] http://pietervanostaeyen.wordpress.com/2013/07/15/abu-bakr-al-baghdadi-a-short-biography-of-the-isis-sheikh oraz thumaczenie angielskie: The Biography of Sheikh Abu Bakr Al Baghdadi, [online] https://archive.org/details/TheBiographyOfSheikhAbuBakrAlBaghdadi.

11 Np. P. Beaumont, Abu Bakr al-Baghdadi. The Isis Chief with the Ambition to Overtake al-Qaida, „The Guardian” 2014, 12 VI, [online] http://www.theguardian.com/world/2014/jun/12/baghdadi-abu-bakr-iraq-isis-mosul-jihad; Profile: Abu Bakr al-Baghdadi; M. Chulov, Abu Bakr al-Baghdadi Emerges from Shadows to Rally Islamist Followers, „The Guardian” 2014, 6 VII, [online] http://www. theguardian.com/world/2014/jul/06/abu-bakr-al-baghdadi-isis.

12 Uczelnia taka nie istnieje. Być może chodziło o Szkołę Nauk Teologicznych na Uniwersytecie Bagdadzkim. 
Do ISIS miał al-Baghdadi trafić po wyjściu na wolność. Początkowo był członkiem lokalnej rady konsultacyjnej, stopniowo zyskiwał zaufanie, stając się kluczowym doradcą ówczesnego lidera ISIS Abu Umara al-Baghdadiego. To on miał go naznaczyć na swojego następcę. Ostatecznie władzę w organizacji objął w 2010 roku, gdy Abu Umar poległ pod Al-Falludżą.

Al-Baghdadiego przyrównuje się coraz częściej do Usamy ibn Ladina, określając go jako najbardziej niebezpiecznego terrorystę na świecie. Doniesienia medialne podkreślają jednak, że przerósł on ibn Ladina, ponieważ jest bardziej brutalny, zaciekły i bardziej antyamerykański. Z kolei jego biografia zamieszczona w Internecie podkreśla dużą wiedzę teologiczną, co sprawia wrażenie, że jest swoistym dżihadystą filozofem ${ }^{13}$, który wie, co i dlaczego robi, a zatem używa przemocy dla wyższych celów, przestrzegając przy tym zasad religii. Al-Baghdadi jest przedstawiany jako człowiek czynu - a zatem aktywnie działający taktyk wojenny, umiejący zorganizować swoich bojowników i nieprzebierający w środkach, aby osiągnąć swój cel. To może przyciągać w szeregi ISIS młodych dżihadystów, którzy są chętni do wzięcia spraw w swoje ręce, a zatem zaangażowania się w faktyczną walkę dla wyższego dobra ${ }^{14}$.

Przemawiając 4 lipca 2014 roku, al-Baghdadi pokazał się publicznie po raz pierwszy, już jako kalif Ibrahim Awwad ${ }^{15}$, wywołując kolejne spekulacje na temat tego, czy to faktycznie on, czy jego sobowtó ${ }^{16}$. Ubrany był w czarną długą szatę i turban, co miało nawiązywać stylizacją do dynastii Abbasydów ${ }^{17}$. Chodzi tu najpewniej o kalifa al-Mansura (754-775), który ustanowił czerń kolorem warstwy rządzącej, ponieważ kalifowie późniejsi - a zwłaszcza al-Mutawakkil (847-861) - słynęli z zamiłowania do mody. Czarna abaja i turban nie są jednak szczególnym wyróżnikiem Abbasydów; noszą je także współcześni szajchowie, zwłaszcza szyiccy ${ }^{18}$, a także religijni muzułmanie, jako symbol swojego oddania religii ${ }^{19}$.

Przyrównywanie al-Baghdadiego do Abbasydów wiąże się najpewniej z tym, że to właśnie w Iraku, w Bagdadzie, mieli oni swoją siedzibę. Te, podobnie jak i inne porównania al-Baghdadiego do poprzednich kalifów, dywagacje na temat tego, czy sposób

13 P. Beaumont, Abu Bakr al-Baghdadi...

14 Profile: Abu Bakr al-Baghdadi.

15 Ibrahim Awwad ma być jego prawdziwym imieniem. W tym sensie nie nawiązuje do żadnego z kalifów o imieniu Ibrahim.

16 Za tą ostatnią wersją były w szczególności władze Iraku, którym ukrywający się al-Baghdadi był bardziej na rękę. Jeżeli faktycznie pokazałby się publicznie, oznaczałoby to, że poczuł się na tyle pewnie, że nie musi działać z ukrycia.

17 M. Chulov, Abu Bakr al-Baghdadi...

18 Z kolei flaga ISIS - biała szahada na czarnym tle - wpisuje się w styl flag wielu innych organizacji radykalnego islamu. Czarna flaga miała wskazywać na przybycie Mahdiego. Kolor ten obrali również Abbasydzi na swoją flagę. Przed nimi czarny kolor przywoływał raczej negatywne skojarzenia. Z kolei czarny turban jako nakrycie głowy był popularny już w pierwszych wiekach kalifatu i symbolizował namaszczenie przez Boga Mahometa na proroka islamu. Por.J. Kister, „The Crowns of this Community”... Some Notes on the Turban in the Muslim Tradition, "Jerusalem Studies in Arabic and Islam” 2000, nr 24, s. 232. 
jego powołania na to stanowisko mieści się w dotychczasowej praktyce, a także w jakim stopniu tereny znajdujące się pod kontrolą ISIS przypominają terytorium kalifatu, nadają mu - już przez sam fakt porównywania - legitymację jako kalifowi albo quasi-kalifowi. Symptomatyczne w tym kontekście jest poświęcenie uwagi mediów, nie tylko społecznościowych, zegarkowi, jaki miał na ręce al-Baghdadi w czasie swojego przemówienia ${ }^{20}$. Postać kalifa - a taką wykreował al-Baghdadi, zaś wizerunek ten umocniły i upowszechniły środki masowego przekazu - nie współgra z nowoczesnością reprezentowaną przez zegarek. Gdyby był zwykłym przywódcą organizacji terrorystycznej, ten szczegół nie wzbudziłby pewnie takiego zainteresowania ${ }^{21}$.

\section{PAŃSTWO MUZUŁMAŃSKIE JAKO PRODUKT MARKETINGOWY}

Nie jest możliwe poznanie prawdziwych celów, jakie przyświecały al-Baghdadiemu i jego poprzednikom w momencie powoływania kalifatu. Być może chodziło o utworzenie zrębów dla zapomnianego, a cieszącego się przecież świetnością, kalifatu obejmującego muzułmanów na całym świecie. Można jednak popatrzeć na kalifat jako na innowacyjny produkt marketingowy.

Utworzenie kalifatu i podtrzymanie jego legitymacji przynajmniej w takim stopniu, aby nie rozgromiły go inne wojska, jest zadaniem ambitnym, ale i opłacalnym z punktu widzenia tych, którzy porywają się na taki czyn. Wynika to z kilku powodów:

1) Jest innowacyjne i daje tym samym prymat nad innymi organizacjami, które mogłyby planować podobny ruch. Choć w historii świata muzułmańskiego już od czasów dynastii Abbasydów mieliśmy do czynienia z funkcjonowaniem najpierw dwóch, a potem kilku konkurujących ze sobą kalifatów, to zaraz po śmierci Mahometa - a przecież ten czas jest najważniejszy dla salafitów i to jego właśnie biorą sobie za wzór - był tylko jeden kalifat. Teoretycznie zatem inni salafici powinni podporządkować się al-Baghdadiemu, a już na pewno nie stwarzać mu konkurencji ${ }^{22}$.

2) Wizja odtworzenia kalifatu ma charakter utopijny i jest przez to kusząca. Obiecuje możliwość tworzenia zrębów państwa na wzór tego, które utworzył Ma-

20 Was it a Rolex? Caliph's Watch Sparks Guesses, Al-Arabijja, 6 VII 2014, [online] http://english. alarabiya.net/en/variety/2014/07/06/Was-it-a-Rolex-Caliph-s-watch-sparks-guesses.html.

21 Podobne zainteresowanie, acz nieco mniejsze, wywołał swego czasu zegarek Usamy ibn Ladina. Ponownie wiąże się to ze stereotypowym postrzeganiem salafitów jako ludzi tradycji, trzymających się z dala od jakichkolwiek przejawów nowoczesności, zwłaszcza zachodnich. Nic bardziej mylnego, albowiem muzułmańscy fundamentaliści bardzo skwapliwie korzystają z zachodnich wynalazków nie tylko broni, ale i nowoczesnych technologii komunikacyjnych.

22 Tymczasem Agencja Reutera podaje, że na granicy egipsko-libijskiej zbierają się radykalni bojownicy muzułmańscy, których dalekosiężnym celem ma być utworzenie na terenie Egiptu kalifatu. Biorąc pod uwagę, w jaki sposób prezydent Abd al-Fattah as-Sisi rozprawił się z Braćmi Muzułmanami, wybór Egiptu na kolejny kraj, który należy podbić, wydaje się uzasadniony. Por. EXCLUSIVE-Egyptians Fear Islamist Militants Gathering on Libyan Border, Reuters, 13 VI 2014, [online] http://af.reuters.com/ article/commoditiesnews/idafl4n0pm3fv20140713. 
homet. Fakt, że jest to okupione krwią i przemocą, wydaje się mieć znaczenie drugorzędne przynajmniej dla tych, którzy decydują się wstąpić w szeregi organizacji al-Baghdadiego. Według badania sondażowego z 2007 roku zrealizowanego w Egipcie, Indonezji, Maroku i Pakistanie znaczna większość respondentów (od 67\% w Egipcie do 74\% w Pakistanie, w Indonezji jedynie 49\%) uważa, że państwa muzułmańskie powinny zostać zjednoczone w kalifat ${ }^{23}$. Nie można zakładać, że chodzi tu o twór, który powstał z inicjatywy al-Baghdadiego, podkreśla to jednak niewątpliwy sentyment do instytucji kalifatu wśród muzułmanów.

3) Utworzenie kalifatu oznacza w perspektywie długookresowej zmianę taktyki walki z Zachodem. Obecnie jest to mniej lub bardziej (a czasami w ogóle) powiązana ze sobą sieć organizacji terrorystycznych, z których każda własnymi siłami stara się walczyć $\mathrm{z}$ wrogiem. Zjednoczenie ich w kalifacie daje efekt synergii poprzez połączenie sił i środków. Zmienia zarazem sposób walki. Docelowo kalifat ma objąć terytorium państw muzułmańskich i podporządkować sobie resztę świata. Prowadzenie walki zbrojnej jako twór państwowy zwiększa możliwy repertuar środków. Zmiana taktyki ma jeszcze znaczenie symboliczne. Odnosi się bowiem do działań, jakie podjął Mahomet, jednocząc pod szyldem islamu plemiona arabskie, które wspólnie stanowiły poważne zagrożenie dla sąsiadujących imperiów ${ }^{24}$.

Od początku powołania kalifatu ISIS wydawał różnego rodzaju spektakularne oświadczenia i deklaracje. Niektóre z nich są faktycznie autorstwa władz organizacji, inne są pewnie jedynie im przypisywane. Można podzielić je na dwie kategorie. Pierwszą stanowią zapowiedzi spektakularnych akcji, drugą zaś niezwykle brutalne akty przemocy.

Przykłady z kategorii pierwszej zaskakują swoją dalekosiężnością. Według oświadczenia z 1 lipca 2014 roku członek ISIS miał zapowiedzieć zniszczenie Al-Kaby, ponieważ wiąże się ona z czczeniem kamieni. Ostatecznie wiadomość nie została potwierdzona $^{25}$. Cztery dni później inni dwaj członkowie organizacji zapowiedzieli podbój Hiszpanii; na wyemitowanym filmie porozumiewali się w języku hiszpańskim, co zaniepokoiło mieszkańców Półwyspu Iberyjskiego ${ }^{26}$. Niecały tydzień później ISIS miał wystosować do FIFA ostrzeżenie, że zamierza zbombardować mistrzostwa świata w piłce nożnej w Katarze w 2022 roku $^{27}$. Wszystkie te informacje bez trudu trafiają do środków masowego przekazu.

23 Pytanie to zostało zadane w specyficznym kontekście, albowiem respondenci wypowiadali się na temat celów Al-Ka’idy. Por. S. Kull i in., Muslim Public Opinion on US Policy, Attacks on Civilians and al Qaeda, University of Maryland, 24 IV 2007, s. 15, [online] http://www.worldpublicopinion.org/ pipa/pdf/apr07/START_Apr07_rpt.pdf.

24 N. Kazimi, The Caliphate Attempted...

25 Y. Hafiz, Reported ISIS Member Says They Will Destroy The Kaaba in Mecca, „Kill Those Who Worship Stones" [UPDATE], Huffington Post, 1 VII 2014, [online] http://www.huffingtonpost. com/2014/07/01/isis-destroy-kaaba-mecca_n_5547635.html?ncid=fcbklnkushpmg00000051.

26 „We'll Take Back Spain”. Fighters Claim ISIS to Seize „Occupied Lands”, RT, 4 VII 2014, [online] http://rt.com/news/170480-spain-isis-invade-threat.

27 F. Aani, Cup, ISIS Warns FIFA, Qatar Chronicle, [online] http://www.qatarchronicle.com/ happenings/52770/breaking-news-we-will-bomb-the-qatar-world-cup-isis-warns-fifa. 
Oświadczenia te mają raczej charakter populistyczny i są ukierunkowane na wywołanie efektu medialnego, aniżeli stanowią zapowiedź faktycznych działań. Trudno bowiem zakładać, że strategia ISIS sięga faktycznie ponad dekadę naprzód. Co więcej, deklaracje trafiają w czułe punkty - wmurowany w narożnik Al-Kaby Czarny Kamień faktycznie był czczony przez politeistów w czasach przedmuzułmańskich, imperium arabsko-muzułmańskie w czasach swojej świetności rzeczywiście obejmowało Hiszpanię, a Katar - ze względu na swoje bogactwo i coraz częstsze mieszanie się w politykę regionalną - stanowi obiekt zazdrości niejednego mieszkańca Bliskiego Wschodu; inna sprawa, że piłka nożna - zdominowana przez Zachód - niekoniecznie jest dyscypliną sportu, którą powinien uprawiać muzułmanin. Zarazem owe deklaracje wpisują się w swoistą metanarrację w tym sensie, że kody przekazu są na tyle proste, iż zrozumieć je może każdy (np. dlaczego celem jest Hiszpania, a nie Madagaskar).

Druga kategoria relacji medialnych odnosi się do bieżącej działalności ISIS. Dotyczy nie tyle sukcesów organizacji na polu walki, ile raczej swoistej otoczki medialnej sensacji wokół tych wydarzeń ${ }^{28}$. W połowie czerwca 2014 roku członkowie ISIS mieli skraść z mosulskiego banku ponad $400 \mathrm{mln}$ USD, co przekształciło organizację w najzamożniejsze tego typu terrorystyczne ugrupowanie na świecie. Doniesienia te zaczęly być jednak podważane nie tyle w zakresie wartości budżetu, jakim dysponuje ISIS, ile raczej w kwestii źródła tych funduszy ${ }^{29}$. Tego samego dnia, w którym ogłoszono kalifat, świat obiegła także informacja o ukrzyżowaniu ośmiu przeciwników Baszszara al-Asada (i przy okazji dżihadystów) przez członków ISIS ${ }^{30}$. Wcześniejsze doniesienia mówią o około 200 osobach zamordowanych podczas masowych egzekucji w Iraku ${ }^{31}$, choć sama organizacja przyznaje się do liczby znacznie wyższej (1,7 tys. irackich żołnierzy $)^{32}$.

Tuż po ogłoszeniu kalifatu pojawiło się doniesienie o emisji paszportów dla mieszkańców kalifatu. Organem wydającym miał być Al-Chilafa al-Islamijja, czyli Kalifat Muzułmański, a informacja na dole głosiła, że jeżeli posiadaczowi paszportu zostanie wyrządzona krzywda, kalifat użyje siły wojskowej, aby go wspomóc ${ }^{33}$. Wiadomość ta

28 Niezależnie od tego, co można pokazać w środkach masowego przekazu (a zatem - co da się zweryfikować i nie przeraża brutalnościa), na YouTubie znaleźć można dziesiątki, jeżeli nie setki, filmików przedstawiających zbrodnie dokonywane przez członków ISIS na przeróżnych kategoriach społecznych - żołnierzach irackich, chrześcijanach, szyitach, kobietach i in. Filmiki trwają od kilkudziesięciu do kilkuset sekund i są nagrane amatorsko. Trudno powiedzieć, kto i w jakim celu je nagrał i opublikował.

R. Windrem, U.S. Official Doubts ISIS Mosul Bank Heist Windfall, NBC News, 24 VI 2014, [online] http://www.nbcnews.com/storyline/iraq-turmoil/u-s-official-doubts-isis-mosul-bank-heist-windfall-n 139846.

ISIS Crucify Eight Anti-Asad Fighters in Syria - Watchdog, Russia Today, 29 VI 2014, [online] http:// rt.com/news/169236-isis-execute-rebels-syria.

31 „ISIS Commits Mass Murder, Advertises it". Iraq Executions Detailed, Russia Today, 27 VI 2014, [online] http://rt.com/news/168916-isis-iraq-war-crimes.

32 ISIS „Execute” 1,700 Iraqi Soldiers, Post Gruesome Pictures (GRAPHIC), Russia Today, 16 VI 2014, [online] http://rt.com/news/166092-iraq-militants-mass-executions.

33 ISIS Allegedly Issues „Caliphate” Passport, Al-Arabijja, 5 VII 2014, [online] http://english.alarabiya. net/en/News/middle-east/2014/07/05/ISIS-allegedly-issues-caliphate-passport.html. 
nie została potwierdzona. Dodatkowym strumieniem funduszy na rozwój kalifatu miałyby być dotacje w bitcoinach - jako niewykrywalne dla służb państwowych, a ponadto zgodne z prawem szar'iatu ${ }^{34}$. Równolegle członkowie organizacji zaczęli rozprawiać się z miejscami kultu sprzecznymi z ich rozumieniem islamu - w ciągu kilku dni od założenia kalifatu zniszczyli przynajmniej cztery groby znanych sunnitów lub sufich, które były odwiedzane przez wiernych, a także co najmniej sześć meczetów szyickich; antyszyizm wydaje się jedną z głównych osi ideologicznych ISIS. Proces niszczenia był starannie przygotowany - w przypadku grobów użyto buldożerów, a w stosunku do meczetów - ładunków wybuchowych, zaś przebieg akcji sfilmowano i umieszczono online ${ }^{35}$. Nie miną tydzień, a pojawiły się kolejne spektakularne doniesienia na temat działalności ISIS. Organizacja miała przejąć materiały nuklearne i broń chemiczną i w ten sposób zagrozić całemu światu ${ }^{36}$.

ISIS działa niewątpliwie z rozmachem i jest gotowe do użycia wszelkich środków, aby osiągnąć swój cel. Akty przemocy i brutalność mają przede wszystkim podkreślić siłę ISIS i zastraszyć wrogów - zarówno tych walczących, jak i potencjalnych ${ }^{37}$. Działania organizacji ponownie wpisują się w pewną metanarrację, tym razem na temat prawa muzułmańskiego. ISIS stosuje skrajną interpretację szari’atu, używając hudud (czyli kar koranicznych), a także walcząc ze wszelkimi innowacjami w religii (bida). Nadając okrucieństwu legitymację religijną, ISIS potęguje efekt medialny. Wszak islam w mediach od dawna przedstawiany jest w taki sposób, że wywołuje strach i poczucie zagrożenia ${ }^{38}$.

Nie należy zarazem wątpić, że silna retoryka fundamentalistyczna i bardzo literalne rozumienie źródeł prawa muzułmańskiego mogą przyciągać niektórych muzułmanów i prowadzić do ich radykalizacji. To również jest efekt, który chce osiągnąć ISIS. Założeniem wyjściowym jest w tym wypadku takfir, czyli oskarżenie o niewiarę. Jest to procedura znana z klasycznej myśli muzułmańskiej, zapoczątkowana przez charydżytów, radykalny ruch, który nie opowiedział się po żadnej stronie w konflikcie o sprawowanie władzy w gminie muzułmańskiej między Alim ibn Abi Talibem a Mu’awiją - założycielem dynastii Umajjadów. Początkowo charydżyci wspierali Alego, ale gdy zdecydował się na negocjacje podczas bitwy pod Siffin (657 r.), odwrócili się od niego. Negocjacje oznaczały bowiem, że decyzję o tym, kto obejmie spuściznę po Mahomecie, podejmą

34 T. Chesire, Global Jihad „Could Be Funded With Bitcoin”, Sky News, 7 VII 2014, [online] http://news. sky.com/story/1296508/global-jihad-could-be-funded-with-bitcoin.

35 ISIS Destroys Shrines, Shiite Mosques in Iraq, Al-Arabijja, 5 VII 2014, [online] http://english.alarabiya. net/en/News/middle-east/2014/07/05/ISIS-destroys-Shiite-mosques-shrines-in-Iraq.html.

36 „Na linii frontu". Irak: terroryści z ISIS zdobyli materiaty nuklearne, Bagdad apeluje o pomoc, Onet. pl, 10 VII 2014, [online] http://wiadomosci.onet.pl/tylko-w-onecie/na-linii-frontu-irak-terrorysci-z-isis-zdobyli-materialy-nuklearne-bagdad-apeluje-o/bs2xm.

37 Równolegle ISIS stara się odzyskać względy ludności lokalnej i wymazać z jej pamięci okrucieństwa przeszłości. Członkowie organizacji próbują nawiązywać z ludnością syryjską przyjacielskie relacje prowadzą dyskusje, zapewniają podstawowe dobra i usługi, organizują czas dzieciom. Por. A. Zelin, Al-Qaeda in Syria. A Closer Look at ISIS (Part I), „Policy Watch” 2013, 10 IX, [online] http://www. washingtoninstitute.org/policy-analysis/view/al-qaeda-in-syria-a-closer-look-at-isis-part-i.

38 Anegdotycznym dowodem niechaj będzie książeczka o znamiennym tytule: A. Marek, A. Nalborczyk, Nie bój się islamu. Leksykon dla dziennikarzy, przedm. J. Danecki, Kraków 2004. 
ludzie, a nie Bóg. Z punktu widzenia charydżytów obie strony konfliktu sprzeniewierzyły się islamowi, a zatem były niewiernymi, których należało zgładzić. $\mathrm{O}$ ile Mu’awija odniósł jedynie niewielkie obrażenia, o tyle zamach na Alego ibn Abi Taliba się powiódł; Ali został ugodzony zatrutą strzałą podczas porannej modlitywy i zmarł kilka dni później.

Koncepcja takfiru stała się kluczowa dla działalności różnego rodzaju grup fundamentalistycznych, przy czym nie każda z nich podejmowała w tej kwestii zasadnicze kroki. Niektóre ugrupowania muzułmańskie decydowały się na eskapizm ${ }^{39}$, czyli wycofanie ze społeczeństwa i założenie odrębnej wspólnoty, inne zaś od razu przechodziły do dżihadu - rozumianego wąsko, jako walka z niewiernymi, lub do dawa - prozelityzmu - jak w przypadku niektórych ugrupowań neofundamentalistycznych.

ISIS prowadzi i dżihad, i dawa. Ten pierwszy znany jest z codziennych doniesień z frontu walki w Iraku i Syrii, warto więc przyjrzeć się drugiemu. Państwo Muzułmańskie publikuje kluczowe wystąpienia swojego przywódcy nie tylko po arabsku, ale również po angielsku, a do dystrybucji materiałów używa mediów społecznościowych. Uderza graficzna oprawa tych materiałów, która subtelnie łączy elementy orientalne i zachodnią stylistykę (co odróżnia je od publikacji typowo arabskich), a także - co ciekawe - naukowa transkrypcja słów pochodzenia arabskiego (ISO) wraz z ich tłumaczeniem w nawiasie. Działalnością publikacyjną zajmuje się specjalna komórka ISIS o nazwie Al-Hayat Media Center. Teksty publikacji są bezbłędnie zredagowane językowo i mają na celu rekrutację nowych członków. Obok ulotek, filmików, w których dżihadyści przemawiają do nowych rekrutów w językach europejskich, ISIS wydaje także gazetkę „Islamic State News” dostępną w języku angielskim i niemieckim. Każdy numer zawiera kilkanaście stron, głównie zdjęć z podpisami, jednak pod kątem oprawy graficznej gazetka nie odróżnia się od zachodnich kolorowych czasopism o tematyce społeczno-politycznej. Z kolei w innej publikacji cyklicznej, „Islamic State Report”, przeczytać można wywiady z czołowymi osobami w kalifacie, a także dowiedzieć się o bieżącej działalności administracyjnej tamże.

Niech świat wie, że dzisiaj żyjemy w nowej erze. Ktokolwiek byt niebaczny, musi stanać w gotowości. Ktokolwiek spat, musi sie obudzić. Ktokolwiek przeżyt szok i zachwyt, musi pojąć. Muzutmanie wydają dzisiaj gtośne, piorunujace oświadczenie i maja ciężkie buty. Mają oświadczenie, które sprawi, że świat ustyszy i zrozumie znaczenie terroryzmu, a buty zdepczq idola nacjonalizmu, zniszcza idola demokracji i odkryja jej zboczona naturę ${ }^{40}$.

39 Koncepcja ta nawiązywała do ideologii charydżytów i składała się z dwóch elementów: oskarżenia o niewiarę (takfir) i wywędrowania (hidżra). Hidżra (analogia do wędrówki Mahometa z Mekki do Medyny w 622 roku) mogła być rozumiana dosłownie - jako założenie odrębnej wspólnoty, „komuny” (np. Stowarzyszenie Muzułmanów założone w 1971 roku przez Szukriego Mustafę), lub w przenośni - jako wewnętrzne odseparowanie się od „świata niewiernych”.

40 A Message to the Mujabidin and the Muslim Ummah in the Month of Ramadan from Amirul-Mu'min Abu Bakr al-Husayni al-Qurashi al-Baghdadi, Al-Hayat Media Center, 1 VII 2014, s. 4, [online] 
Niewątpliwie nadeszła nowa era dla globalnego dżihadyzmu i w tym zakresie nie sposób nie przyznać al-Baghdadiemu słuszności. Co prawda, o zbliżających się nowych czasach marzyło wielu, w tym klasyczni teoretycy fundamentalizmu muzułmańskiego, jak chociażby Mustafa as-Siba’i, jednak to al-Baghdadi zaczął przekształcać te marzenia w rzeczywistość.

Utworzenie kalifatu przez organizację al-Baghdadiego nie spotkało się z jednogłośnym ciepłym przyjęciem w środowisku dżihadystów. Już jesienią 2013 roku, a zatem ponad rok przed powołaniem kalifatu, przeciw pomysłowi przekształcenia ówczesnego emiratu, Muzułmańskiego Państwa Iraku, w kalifat wypowiedzieli się bardzo krytycznie dwaj ideolodzy dżihadu - Abu Muhammad al-Makdisi ${ }^{41}$ oraz Abu Katada al-Filastini. Al-Makdisi zarzuca ISIS przede wszystkim niewłaściwość stosowanych środków, a zwłaszcza wykorzystywanie przemocy ${ }^{42}$. Z kolei Abu Katada wskazuje, że nie można jeszcze mówić o stopniu organizacji państwowej, która legitymizowałaby używanie określenia „kalifat”, ale przede wszystkim neguje samozwańczy sposób wyboru kalifa, który przyrównuje do szyickiej doktryny politycznej ${ }^{43}$. Zważywszy na ogólnie deklarowaną niechęć salafitów do szyizmu jako aberracji w islamie, słowa te mają bardzo silny wydźwięk.

Aymenn Jawad Al-Tamimi już w 2013 roku wskazywał, że działalność i dążenia ISIS cieszą się dużym poparciem wśród muzułmanów (zwłaszcza z Arabii Saudyjskiej) w porównaniu do innych organizacji muzułmańskich, jak chociażby Dżabhat an-Nusry i jej lidera szajcha Dżaulaniego ${ }^{44}$. Na swój sposób, ustanawiając kalifat, al-Baghdadi podważył działalność Al-Ka’idy, dla której kalifat był celem ostatecznym, będącym do zrealizowania w bliżej nieokreślonej, oddalonej przyszłości ${ }^{45}$.

Jak potoczy się przyszłość samozwańczego niby-państwa, zależy w dużej mierze od tego, w jaki sposób reagować będzie jego bliższe i dalsze otoczenie. Jako otoczenie bliższe należy rozumieć inne muzułmańskie organizacje radykalne, które przyłączą się do

https://azelin.files.wordpress.com/2014/07/abc5ab-bakr-al-e1b8a5ussaync4ab-al-qurayshc4ab-al-baghdc481dc4ab-22message-to-the-mujc481hidc4abn-and-the-islamic-ummah-in-the-month-of-ramae1b88dc481n22-en.pdf. Tłumaczenie własne.

41 Niechęć do ISIS - zarówno do stosowania przemocy przez to ugrupowanie, jak i do utworzenia kalifatu - sprawiła, że al-Makdisiemu zawieszono karę pozbawienia wolności i w czerwcu 2014 roku wypuszczono go z jordańskiego więzienia. Por. A. Abuqudairi, Jordan Releases Anti-ISIL Salafi Leader, Al-Dżazira, 17 VI 2014, [online] http://www.aljazeera.com/news/middleeast/2014/06/ jordan-releases-anti-isil-salafi-leader-2014617121457552506.html.

42 J. Wagemakres, Protecting Jihad. The Sharia Council of the Minbar al-Tawhid wa-l-Jihad, „Middle East Policy Council" 2011, Vol. 18, nr 2.

43 Caliphate Now. Jihadis Debate the Islamic State, [online] http://www.jihadica.com/caliphate-now-jihadis-debate-the-islamic-state.

44 A. Al-Tamimi, Foreign Support for Sheikh Abu Bakr al-Baghdadi and the Islamic State of Iraq and ash-Sham, Jihadology.org, 22 VIII 2013, [online] http://jihadology.net/2013/08/22/musings-of-an-iraqi-brasenostril-on-jihad-bayah-to-baghdadi-foreign-support-for-sheikh-abu-bakr-al-baghdadi-and-the-islamic-state-of-iraq-and-ash-sham.

45 A. Zelin, The War between ISIS and al-Qaeda for Supremacy and the Global Jihadist Movement, Research Notes, The Washington Institute for Near East Policy, 2014, nr 20. 
ISIS albo będą starały się podważyć jej legitymację do zarządzania kalifatem. Otoczenie bliższe to również wojska irackie - wspierane ewentualnie przez inne siły - które muszą odzyskać panowanie nad swoim państwem. W tle są także Kurdowie, którzy w powstaniu Państwa Muzułmańskiego, a tym samym początku rozpadu Iraku, upatrzyli możliwość utworzenia własnego państwa. W dalszym otoczeniu losy Państwa Muzułmańskiego zależą od tego, w jaki sposób do tej idei podejdą sami muzułmanie i ilu z nich będzie gotowych wspierać je ideologicznie, fizycznie bądź finansowo. Utworzenie kalifatu przez al-Baghdadiego jednoznacznie i ostro potępili uczeni muzułmańscy ${ }^{46}$, a także Międzynarodowa Unia Uczonych Muzułmańskich ${ }^{47}$. Z pewnością jednak znajdzie się niejeden, dla którego taka utopia będzie kusząca.

\section{BIBLIOGRAFIA}

Aani F., Cup, ISIS Warns FIFA, Qatar Chronicle, [online] http://www.qatarchronicle.com/ happenings/52770/breaking-news-we-will-bomb-the-qatar-world-cup-isis-warns-fifa.

Abuqudairi A., Jordan Releases Anti-ISIL Salafi Leader, Al-Dżazira, 17 VI 2014, [online] http://www.aljazeera.com/news/middleeast/2014/06/jordan-releases-anti-isil-salafi-leader-2014617121457552506.html.

Al-Tamimi A., Foreign Support for Sheikh Abu Bakr al-Baghdadi and the Islamic State of Iraq and ash-Sham, Jihadology.org, 22 VIII 2013, [online] http://jihadology.net/2013/08/22/ musings-of-an-iraqi-brasenostril-on-jihad-bayah-to-baghdadi-foreign-support-for-sheikh-abu-bakr-al-baghdadi-and-the-islamic-state-of-iraq-and-ash-sham.

Bajan ialan kijam "daulat al-irak al-islamijja”, Ministerstwo Informacji Muzułmańskiego Państwa Iraku, 15 XI 2008, [online] http://www.tawhed.ws/r?i=xsdcfre4.

Beaumont P., Abu Bakr al-Baghdadi. The Isis Chief with the Ambition to Overtake al-Qaida, „The Guardian” 2014, 12 VI, [online] http://www.theguardian.com/world/2014/jun/12/ baghdadi-abu-bakr-iraq-isis-mosul-jihad.

Bunzel C., The Caliphate's Scholar-in-Arm, Jihadica, 9 VII 2014, [online] http://www.jihadica. com/the-caliphate\%E2\%80\%99s-scholar-in-arms.

Chesire T., Global Jihad „Could Be Funded With Bitcoin”, Sky News, 7 VII 2014, [online] http://news.sky.com/story/1296508/global-jihad-could-be-funded-with-bitcoin.

Caliphate Now. Jihadis Debate the Islamic State, [online] http://www.jihadica.com/caliphate-now-jihadis-debate-the-islamic-state.

Chulov M., Abu Bakr al-Baghdadi Emerges from Shadows to Rally Islamist Followers, „The Guardian" 2014, 6 VII, [online] http://www.theguardian.com/world/2014/jul/06/abu-bakr-al-baghdadi-isis.

46 S. Mandhai, Muslim leaders reject Baghdadi's caliphate, Al-Dżazira, 7 VII 2014, [online] http:// www.aljazeera.com/news/middleeast/2014/07/muslim-leaders-reject-baghdadi-caliphate-201477 44058773906.html.

47 Prominent scholars declare ISIS caliphate 'null and void', Middle East Monitor, 5 VII 2014, https:// www.middleeastmonitor.com/news/middle-east/12567-prominent-scholars-declare-isis-caliphate-null-and-void. 
EXCLUSIVE-Egyptians Fear Islamist Militants Gathering on Libyan Border, Reuters, 13 VI 2014, [online] http://af.reuters.com/article/commoditiesnews/idafl4n0pm3fv20140713. Hafiz Y., Reported ISIS Member Says They Will Destroy The Kaaba in Mecca, „Kill Those Who Worship Stones" [UPDATE], Huffington Post, 1 VII 2014, [online] http://www.huffingtonpost.com/2014/07/01/isis-destroy-kaaba-mecca_n_5547635.html?ncid=fcbklnkushpmg00000051.

ISIS Allegedly Issues „Caliphate” Passport, Al-Arabijja, 5 VII 2014, [online] http://english.alarabiya.net/en/News/middle-east/2014/07/05/ISIS-allegedly-issues-caliphate-passport. html.

„ISIS Commits Mass Murder, Advertises it”. Iraq Executions Detailed, Russia Today, 27 VI 2014 , [online] http://rt.com/news/168916-isis-iraq-war-crimes.

ISIS Crucify Eight Anti-Asad Fighters in Syria - Watchdog, Russia Today, 29 VI 2014, [online] http://rt.com/news/169236-isis-execute-rebels-syria.

ISIS Destroys Shrines, Shiite Mosques in Iraq, Al-Arabijja, 5 VII 2014, [online] http://english. alarabiya.net/en/News/middle-east/2014/07/05/ISIS-destroys-Shiite-mosques-shrines-in-Iraq.html.

ISIS 'Execute' 1,700 Iraqi Soldiers, Post Gruesome Pictures (GRAPHIC), Russia Today, 16 VI 2014, [online] http://rt.com/news/166092-iraq-militants-mass-executions.

Kazimi N., The Caliphate Attempted. Zarqawi's Ideological Heirs, their Choice for a Caliph, and the Collapse of their Self-Styled "Islamic State of Iraq”, "Current Trends in Islamist Ideology” 2008, Vol. 7.

Kister J., „The Crowns of this Community”... Some Notes on the Turban in the Muslim Tradition, "Jerusalem Studies in Arabic and Islam" 2000, No. 24.

Kull S. i in., Muslim Public Opinion on US Policy, Attacks on Civilians and al Qaeda, University of Maryland, 24 IV 2007, s. 15, [online] http://www.worldpublicopinion.org/pipa/pdf/ apr07/START_Apr07_rpt.pdf.

Marek A., Nalborczyk A., Nie bój się islamu. Leksykon dla dziennikarzy, przedm. J. Danecki, Kraków 2004.

A Message to the Mujabidin and the Muslim Ummah in the Month of Ramadan from Amirul-Mu'min Abu Bakr al-Husayni al-Qurashi al-Baghdadi, Al-Hayat Media Center, 1 VII 2014, [online] https://azelin.files.wordpress.com/2014/07/abc5ab-bakr-al-e1b8a5ussaync4ab-al-qurayshc4ab-al-baghdc481dc4ab-22message-to-the-mujc481 hidc4abn-and-the-islamic-ummah-in-the-month-of-ramae1b88dc481n22-en.pdf.

„Na linii frontu”. Irak: terroryści z ISIS zdobyli materiaty nuklearne, Bagdad apeluje o pomoc, Onet.pl, 10 VII 2014, [online] http://wiadomosci.onet.pl/tylko-w-onecie/na-linii-frontu-irak-terrorysci-z-isis-zdobyli-materialy-nuklearne-bagdad-apeluje-o/bs2xm.

van Ostaeyen P., Abu Bakr al-Baghdadi - a Short Biography of the ISIS Sheikh, 15 VII 2013, [online] http://pietervanostaeyen.wordpress.com/2013/07/15/abu-bakr-al-baghdadi-a-short-biography-of-the-isis-sheikh (tłumaczenie angielskie: The Biography of Sheikh Abu Bakr Al Baghdadi, [online] https://archive.org/details/TheBiographyOfSheikhAbuBakrAlBaghdadi).

Profile: Abu Bakr al-Baghdadi, BBC News, 5 VII 2014, [online] http://www.bbc.com/news/ world-middle-east-27801676. 
Was it a Rolex? Caliph's Watch Sparks Guesses, Al-Arabijja, 6 VII 2014, [online] http://english. alarabiya.net/en/variety/2014/07/06/Was-it-a-Rolex-Caliph-s-watch-sparks-guesses.html.

Wagemakres J., Protecting Jihad. The Sharia Council of the Minbar al-Tawhid wa-l-Jihad, „Middle East Policy Council” 2011, Vol. 18, nr 2.

„We'll Take Back Spain”. Fighters Claim ISIS to Seize „Occupied Lands”, RT, 4 VII 2014, [online] http://rt.com/news/170480-spain-isis-invade-threat.

Windrem R., U.S. Official Doubts ISIS Mosul Bank Heist Windfall, NBC News, 24 VI 2014, [online] http://www.nbcnews.com/storyline/iraq-turmoil/u-s-official-doubts-isis-mosul-bank-heist-windfall-n139846.

Zelin A., Al-Qaeda in Syria. A Closer Look at ISIS (Part I), „Policy Watch” 2013, 10 IX, [online] http://www.washingtoninstitute.org/policy-analysis/view/al-qaeda-in-syria-a-closer-look-at-isis-part-i.

Zelin A., The War between ISIS and al-Qaeda for Supremacy and the Global Jihadist Movement, Research Notes, The Washington Institute for Near East Policy, 2014, nr 20.

Dr hab. Katarzyna GÓRAK-SOSNOWSKA - doktor habilitowany nauk humanistycznych w dyscyplinie religioznawstwo oraz doktor nauk ekonomicznych, pracuje w Szkole Głównej Handlowej w Warszawie w Instytucie Filozofii, Socjologii i Socjologii Ekonomicznej na stanowisku adiunkta oraz pełni funkcję prodziekana Studium Magisterskiego. Opublikowała cztery monografie: Świat arabski wobec globalizacji (2007), Perspektywy świata arabskiego w kontekście Milenijnych Celów Rozwoju (2007), Muzutmańska kultura konsumpcyjna (2011) oraz Deconstructing Islamophobia in Poland (2014). 